\title{
The Impact Of Information Asymetry Towards The Quality Of Accrual Earnings With Good Corporate Governance (GCG) As Moderating Variabel
}

\author{
Mediaty \\ Department of Accountingi, Faculty of Economic, Hasanuddin University, Makassar, Indonesia
}

\begin{abstract}
Asymmetry of information is the information gap between management and owners of the company can be reduced in order to improve the quality of the profit generated by the company. This study aims to examine 1) the effect of information asymmetry on the quality of accrual earnings, 2) the effect of managerial ownership as a moderating variable between information asymmetry with accrual earnings quality, 3) the influence of the composition of the independent board directors as a moderating variable between information asymmetry with accrual earnings quality. Object of study is a manufacturing company listed on the Indonesia Stock Exchange (BEI) for 3 years (2009-2011). Study sample as many as 72 companies. The sampling technique used was purposive sampling. Data were analyzed using SPSS 17.0 for Windows that consists of two types of analysis is multiple regression analysis and analysis of different test t-test. Results of this study indicate that information asymmetry variables significantly influence the quality of accruals and earnings moderating variable of managerial ownership and the variable composition of independen board directorst can be a moderating variable between information asymmetry with accrual earnings quality.
\end{abstract}

Keywords: asymmetry information, quality of earnings accruals, managerial ownership and independent directors.

\section{Introduction}

The financial report is a means of communicating by the manager as the manager of the company to provide financial information to parties outside the corporation. The financial statements are expected to provide information to investors and creditors in making decisions related to their investment funds. Managers as corporate managers more aware of internal information and prospects of the company in the future than the owners (shareholders). Therefore, as the manager, the manager is obliged to provide a signal about the state of the company to the owner. However, sometimes the information submitted is not acceptable according to the actual condition of the company. This condition is known as asymmetric information (Harris, 2004). Asymmetry information between management (agent) with the owner (principal) can provide an opportunity for managers to manage the earnings (earnings management) (Richardson, 1998). This study aims to examine 1) the effect of information asymmetry on the quality of accrual earnings, 2) the effect of managerial ownership as a moderating variable between information asymmetry with accrual earnings quality, 3) the influence of the composition of the independent board directors as a moderating variable between information asymmetry with accrual earnings quality. Object of study is a manufacturing company listed on the Indonesia Stock Exchange for 3 years (2009-2011).

\section{1 asymmetry information}

\section{Conceptual Framework and Hypothesis}

Information asymmetry is an information gap between the agent as the manager (manager) company and the principal, which in this case is the owner of the company. Information obtained by the manager, is a more in-depth information about the state of the company for both current conditions as well as for the prospect of a state company in the future. The gap between management (agent) with the owner (principal) provides the opportunity for managers to act optimistic, for the sake of personal gain (Basu, 1997; Ujiyantho et al, 2007.

Asymmetry of information is then used to trigger the onset of the practice of earnings management in a company. This information asymmetry can be reduced by transparency in the presentation of the financial statements of the principal. Behavioral manipulation by the manager who started such conflicts can be minimized through a monitoring mechanism that aims to alignment the various interests. First, by increasing the company's share ownership by management (managerial ownership) (Jensen et al, 1976; Bernard et al, 1989; Givoly et al, 2002), so that the interests of the owners or shareholders will be aligned with the interests of the manager. Secondly, through the role of monitoring by the board of commissioners (board of directors). Dechow et al (1996) and Beasly (1996) found a significant relationship between board role to financial reporting. They 
found that the size and independence of the board of commissioners with their ability to monitor the financial reporting process.

\subsection{The Quality of Financial Reporting}

Issues relating to the quality of financial reporting is often caused by a conflict of interest between management and stakeholder interests. Management does not always act in the interests of stakeholders, but often management acts to maximize their welfare and securing their positions regardless of the danger posed to other stakeholders, such as employees, investors, creditors and the public. The importance of the differences then this raises the asymmetry of information between the two sides. Information gap between the company and potential investors, will also increase the probability for the company to increase profits and this can not detected by the market.(Ball Ray,et al,1968; Penman,2002;Boediono,2005; Fala,2007). Research by Richardson (1998) proved that the higher the information the higher the income management so as to reduce the quality of earnings information. Earnings information used as a basis for decision making for the company's internal and external, then the earnings information can be referred to as a quality earnings information because it can affect the decisions that will be made for the parties concerned Dechow,1996;Feltham,1996;Gabrielsen,1997; Schipper,2003. Earnings quality in this case that, if the income can provide a response to the interested parties in decision-making about the condition of the company.

\subsection{Good Corporate Governance}

Good Corporate Governance (GCG) is a key element in improving economic efficiency, which includes a set of relationships between the company's management, board, shareholders and other stakeholders Chtourou,2001; Brown,2004;Bahaudin,2011. Corporate governance also provides a structure that facilitates the determination of the objectives of a company, and as a means to determine the performance monitoring techniques (Dean et al, 2004). Based on the description above, it can be formulated as the following hypothesis: Hypothesis 1: asymmetry affects the quality of earnings,

Hypothesis 2: managerial ownership of information can moderate the asymmetry between the quality of earnings.

Hypothesis 3: composition of independent directors can moderate the asymmetry of information between the quality of earnings.

\section{Research Methodology}

Location and Design of the research was conducted at the Indonesian Stock Exchange. By analyzing empirically the influence of asymmetry of information on the quality of earnings accrued by good corporate governance as a moderating variable. This study uses panel data (pooled data). The population in this study are listed companies in Indonesia Stock Exchange in the period 2009-2011. Of 168 manufacturing companies listed on the Stock Exchange, several companies had to be removed because of problems related to the availability, condition, and completeness of the information required in testing so the final sample to 24 firms. Data collection methods used in the form of data files or secondary data obtained from the annual financial statements of companies listed on the Stock Exchange and are available at (http://www.idx.co.id/) and the Indonesian capital market directory (ICMD) in 2009 - 2011. Analysis of the data using two models, the first model to examine the effect of information asymmetry on earnings quality through multiple regression analysis (multiple linear regression) and the second model to test the effect of information asymmetry after moderated by good corporate governance (GCG) which consists of managerial ownership and the composition of independent directors. by using different test t-test. Using SPSS 17.0 for Windows. The results in the form of descriptive statistical analysis and hypothesis testing techniques.

\section{Research Finding and Discussion}

\section{Research Findings}

\subsection{Descriptive Statistical Analysis}

Based on the results of a descriptive analysis of Table 1 and 2 shows that the number of samples (n) of the study there were 24 . Of the number of samples (n), the discretionary accruals variable has a minimum value and a maximum -0.5.09 -11. With an average standard deviation of 1.04801-2.6421dan. As well as the number of observations as much as 72. This shows a sample enterprise data quality tends to show quality of the profit. Information asymmetry has a minimum value of 4:03 and a maximum value of 8.99 with an average of 5.9252 and a standard deviation of 1.2096772 as well as the number of observations. This shows sample data company, has a fairly high information asymmetry. Managerial ownership has a minimum value and a maximum value of 23.08000 .0010 with an average of 3.189972 and the standard deviation of 5.7944661. As well as the number of observations as much as 72. This means that stock ownership by management and 
directors of the average taken 10 percent. independen of board director has a minimum value and a maximum value of 0.2500 with an average of 60.000037 .895556 and standard deviation of 9.8154470 . As well as the number of observations as much as 72 . This means that the number of independen board directors appointed by the parties outside the company more than 25 percent of its commissioners.

Tabel 1. Details of Sampling Data

\begin{tabular}{lll}
\hline No & Description & Amount \\
\hline 1. & Number of Manufacturing Companies listed on the Stock Exchange in 2009 till 2011. & 168 \\
2. & Not present the full report & -96 \\
3. & Do not have information GCG & -47 \\
4. & Fiscal year not ended 31 Desember & -1 \\
& The sample of the company & 24 \\
& Number of observations (24x3 observation period) & 72 \\
\hline
\end{tabular}

Source : Data processed

Tabel 2. Descriptive Statistics

\begin{tabular}{llrrrr}
\hline Description & N & \multicolumn{1}{c}{ Minimum } & Maximum & Average & Standar Deviation \\
\hline K.LABA & 72 & -5.09 & -11 & -2.6421 & 1.04801 \\
INF.ASYMETRI & 72 & 4.03 & 8.99 & 5.9252 & 1.20967 \\
k.manajerial & 72 & .0010 & 23.0800 & 3.189972 & 5.7944661 \\
k.independen & 72 & .2500 & 60.0000 & 37.895556 & 9.8154470 \\
\hline
\end{tabular}

\subsection{Multiple Regression Analysis}

Based on Table 3 and Table 4, it can be seen the coefficient of determination for moderation in the adjusted $\mathrm{R}$ square value is equal to 0.122 means that variations in the quality of earnings is the dependent variable can be explained by variation in the independent variable by $12 \%$ and the remaining $88 \%$ is explained by other variables. Once the data is entered moderating variable of good corporate governance, the adjusted $\mathrm{R}$ square value increased to 0.193 means that earnings quality variations dependent variable that can be explained by the independent variables by $19 \%$ and the remaining $89 \%$ is explained by other variables.

Tabel 3. Coefficient of Determination Before Moderation

\begin{tabular}{lrrrrrr}
\hline Model & R & \multicolumn{2}{c}{ R Square } & Adjusted R quare & \multicolumn{3}{c}{ Std Error of the estimate } \\
\hline 1 & & $.367^{\mathrm{a}}$ & .135 & .122 & .98179 \\
\hline
\end{tabular}

Tabel 4. Coefficient of Determination After Moderation

\begin{tabular}{lrrrrr}
\hline Model & R & \multicolumn{2}{c}{ R Square } & Adjusted R quare & \multicolumn{3}{c}{ Std Error of the estimate } \\
\hline 1 & $.500^{\mathrm{a}}$ & .220 & .193 & .94118 \\
\hline
\end{tabular}

\subsection{T-Test Results}

Based on a statistical test $t$ can be seen in Table 5 asymmetry variable has a negative and significant relationship to the quality of earnings. And when moderated by managerial ownership and composition of independent directors has a significant connection.

Tabel 5. Result of statistical test (t)

\begin{tabular}{|c|c|c|c|c|}
\hline Variable & Unst. Coefficient & Statistic Value (t) & Significance & Result \\
\hline (Constant) & 8.714 & 2.764 & & 0.007 \\
\hline Lnabsinf_asy & -1.723 & -3.3567 & & 0.001 Accepted \\
\hline Lnabsinf_asy*k.man & -1.757 & -3.33 & & 0.001 Accepted \\
\hline Lnabsinf_asy*k.indp & 0.036 & 2.898 & & 0.005 Accepted \\
\hline
\end{tabular}

\subsection{Asymmetry Affects the Quality of Earnings}

\section{Discussion}

This study suggests that information asymmetry has effect significant negative on the quality of earnings. The statistical results showed that the variables significantly the second hypothesis (H1) which states that information asymmetry affects the quality of earnings, is acceptable. Substantial regression of variable asymmetry coefficient is negative indicates that there is a negative relationship between the value of information asymmetry discreationary accrual, where the greater the higher the value of the information asymmetry, discreationary accrual will be smaller, and vice versa. Results of this study are consistent with results of 
previous studies (Richardson, 1998) which found that there is a systematic relationship between magnitut information asymmetry and the level of earnings management Lafond,2006. So the quality of the resulting profit associated with the level of earnings management undertaken by management. Information gap between the two sides, it will be able to lead to the use of accounting methods which can improve the bottom line. And will also be able to trigger high earnings management undertaken by the manager, so it can rise to the misleading information to users of financial statements.

\subsection{Managerial Ownership of Information Can Moderate the Asymmetry between the Quality of Earnings}

Managerial ownership may moderate the relationship asymmetry of information on the quality of the earnings accrual, the second hypothesis $(\mathrm{H} 2)$ is acceptable. The results support the research by Jensen et al, 1976; Jones,1991;Merchan,1994;Warfield,1995;Xie,2003. Theoretically when managerial ownership is high, then the incentive to the possibility of opportunistic behavior of managers will decline. With higher agency problems of managerial ownership is assumed to be on the wane. Fidyati (2004) find evidence that earnings management is conducted has a negative relationship with managerial ownership. This means that the higher the shares owned by management, the higher the quality of earnings. Siallagan and Machfoedz (2006) states that the greater the discretionary accrualsemakin managerial ownership is low Xiong,2006;Pagalung,Gagaring,2006.

The results support the evidence that managerial ownership reduces the urge managers opportunistic behavior.

\subsection{Composition of Independent Directors Can Moderate the Asymmetry of Information between the Qualities of Earnings}

Composition of independent board directors are able to moderate the relationship between information asymmetry on the quality of that accrual earnings. The third hypothesis (H3) is acceptable. The role of the board of commissioners will have an impact on earnings management because the commissioners oversee the balancing of the interests of management that earnings management is not going to happen Morck,1988;Lins,2004. Commissioners can also impact the performance of the company as if the commissioners carry out their duties properly, it can increase the confidence of investors that they would receive a return on the funds they have invested. Results of this study support the results of research conducted by Brown et al (2004) that examined the relationship between the proportion of the board of commissioners with the company's performance in generating earnings quality and found that companies with a high commissioners will have a return on equity yield, profit margin and dividend higher yields Veronica N.P. Siregar,2005; Indrayati,2010.

\section{Conclusion and Recommedations}

Based on the findings in this study that specifically examined the manufacturing company that, the result that information asymmetry significant effect on earnings quality. Managerial ownership and the moderating variable composition of independent board directors is a variable that may moderate the relationship between information asymmetry with accrual earnings quality.

Advisable for the practitioner, or the management as the decision maker needs to put quality information generated company profits. Because earnings information will be used as a basis for decision making for interested parties (stakeholders). Besides, the implementation of Good Corporate Governance (GCG) should also be considered optimal, in order to achieve corporate governance better.

\section{Refferences}

[1] Haris Wibisono. (2004). Pengaruh Earnings Management Terhadap Kinerja Di Seputar SEO. Tesis S2. Magister Sains Akuntansi UNDIP. Tidak dipublikasikan Ball Ray. dan Philip Brown. 1968. An Empirical Evaluation of Accounting Number. Journal of Accounting Research, Autumn.

[2] Dechow, Patricia, Richard Sloan dan Amy Sweeney.1996. Detecting Earnings Management The Accounting Review, 70 : $193-225$.

[3] Feltham, Gerald dan J.Ohlson.1996. Model of Earnings. Journal of Accounting and Economic. September 17 No. 3.

[4] Gabrielsen, Gorm. Jeffrey D. Gramlich dan Thomas Plenborg.1997. Managerial Ownership, Information Content of Earnings, and Discretionary Accruals in a Non-US Setting. Journal of Business Finance and Accounting, Vol.29. No.7 \& 8. September/ Oktober.

[5] Penman, Stephen.H. dan X-J Zhang. 2002. Accounting Conservatism, Quality of earnings,Stock returns.The Accounting Review, 77(2).

[6] Schipper, L. Vincent. 2003. Earnings Quality. Accounting Horizon, Supplement.

[7] Boediono, Gideon S. B. 2005. "Kualitas Laba : Studi Pengaruh Mekanisme Corporate Governance dan Dampak Manajemen Laba dengan menggunakan Analisis Jalur”. Simposium Nasional Akuntansi VIII: Solo.

[8] Fala, Dwi Yana Amalia, 2007. "Pengaruh Konservatisme akuntansi Terhadap Penilaian Ekuitas Perusahaan dimoderasi oleh Good Corporate Governance", Simposium Nasional Akuntansi X: Makassar.

[9] Richardson, V. J. (1998). Information Asymmetry and Earnings Management :Some Evidence. http/www.ssrn.com.

[10] Basu, Sudipta. 1997. The Conservatism Principle m The Asymmetric Timeliness of Earnings, Journal of Accounting and Economics, 24:3-37. 
[11] Ujiyantho, Moh. Arief dan Bambang Agus P. (2007). "Mekanisme Corporate Governance,Manajemen Laba dan Kinerja Keuangan” ,Simposium Nasional Akuntansi X, Makassar.

[12] Jensen Mc., dan Meckling W.H. (1976).Theory of the Firm: Managerial Behaviour Agency Cost and Ownership Structure. Journal of Financial Economics 3(4): 305-360.

[13] Jones, J.J.1991. Earning Management During Import Relief Investigation, Journal of Accounting Research. Vol 29 No.2.

[14] Merchan, Kenneth A. dan Joanne Rockness. 1994. "The Ethics of Managing Earning Investigation. Journal of Accounting and Public Policy.

[15] Warfield, Terry D.,J.J Wild, dan K.L. Wild. 1995. Managerial Ownership, Accounting Choices, and Informativeness of Earnings. Journal of Accounting and Economics 20.

[16] Bernard, V. L., dan T. S. Stober. 1989. The Nature and Amount of Information Reflected in Cash Flows and Accruals. The Accounting Review (October).

[17] Givoly, Dan dan C. Hayn, 2002. Rising Conservatism: Implication for Financial Analisis, Financial Analysis Journal.

[18] Dechow, P.M.1996. Accounting Earnings dan Cash Flows as Measures of Firm Performance :The Role of Accounting Accruals, Journal of Accounting And Economic 18:3-42.

[19] Beasley, M.S.1996. An Empirical Analysis of the Relation Between The board of Director Composition And Financial Statement Fraud. The Accounting Review, Vol.71(4).

[20] Chtourou, SM., J.Bedard, dan L. Courteau.2001. Corporate Governance and Earning Management

[21] Bahaudin, Ahmad dan Provita W. 2011. "Mekanisme Corporate Governance terhadap Konservatisme Akuntansi di Indonesia", Dinamika Sosial Ekonomi, Mei, Volume 7 Nomor 1.

[22] Deni Darmawati, Khomsiyah dan Rika Gelar Rahayu. (2004). Hubungan Corporate Governance dan Kinerja Perusahaan. Simposium Nasional Akuntansi VII: 2004.

[23] Lafond, Ryan., dan Watts, Ross.L. 2006. "The Information Role of Conservative Financial Statements", Social Science Research Network Electronic Paper Collection.http://papers.ssrn.com

[24] Xie, B., WN Davidson, dan P. Dadalt. 2003. Earnings management and corporate governance: the role of the board and the audit committee. Journal of Corporate Finance 9.

[25] Fidyati, Nisa, 2004, "Pengaruh Mekanisme Corporate Governance Terhadap Earning Management pada Perusahaan Seasoned Equity Offering(SEO),” Jurnal Ekonomi, Manajemen \& Akuntansi,Vol.2 No.

[26] Siallagan, Hamonangan dan Mas’ud Machfoedz, 2006,"Mekanisme Corporate Governance,Kualitas Laba, dan Nilai Perusahaan".Proceeding Simposium Nasional Akuntansi I.

[27] Pagalung,Gagaring. 2006. Earning Quality: Determinant Factors and Economic Cosequences., Makalah Simposium Nasional Akuntansi IX:Padang.

[28] Xiong. Y. 2006. Earnings Management and it's Measurement: A Theoritical Perspective. Journal of American Academy of Business : 214:219.

[29] Morck, R., A. Shleifer dan R.W. Vishny. 1988. Management Ownership and Market Valuation: An Empirical Analysis. Journal of Financial Economics, Vol.20.

[30] Lins, Karl V. 2004. Equity Ownership and Firm value Emerging Markets. journal of Financial and Quantitative Analysis. Vol. 38. No. 1 (March)

[31] Brown, LD dan ML Caylor. 2004. Korelasi antara Tata Kelola Perusahaan dan Kinerja Perusahaan. Pemegang Saham Kertas Layanan Kelembagaan Putih.

[32] Veronica N.P. Siregar, Sylvia dan Siddharta Utama. 2005. Pengaruh Struktur Kepemilikan, Ukuran Perusahaan dan Praktek Corporate Governance Terhadap Pengelolaan Laba. Simposium Nasional Akuntansi VIII,. Solo.

[33] Indrayati, Martha R. 2010. "Pengaruh Karakteristik Dewan Komisaris terhadap Tingkat Konservatisme Akuntansi", Skripsi, Fakultas Ekonomi Universitas Diponegoro. 